Original Article

\title{
Efficiency of tick biotherapic on the control of infestation by Rhipicephalus (Boophilus) microplus in Dutch dairy cows
}

\author{
Zilda Cristiani Gazim¹, Fabiana Borges Padilha Ferreira ${ }^{1}$, Aristeu Vieira da \\ Silva $^{2}$, Kelly Cristina Bolognese ${ }^{1}$, Ewerton Merlin¹, Valdeci Messa ${ }^{1}$, Renan \\ Almeida de Jesus ${ }^{3}$, Cesar Alberto Coutinho ${ }^{3}$, Luiz Cláudio Monteiro da Silva ${ }^{4}$
}

(1) University Paranaense - UNIPAR, Umuarana, PR, Brazil; (2) State University of Feira de Santana, Bahia, Brazil;

(3) Nutriphós Company- Nutrição Animal, Brazil; (4)Veterinarian, Brazil.

\begin{abstract}
Background: cattle tick Rhipicephalus (Boophilus) microplus poses serious problems for farmers in Brazil, especially because the parasite easily develops resistance to pesticide agents. For this reason, together with other factors including environmental, human and animal contamination and costs, alternative approaches have been sought for. Aims: this study sough to evaluate the efficiency of a tick biotherapic on tick-infested cows. Methods: 34 dairy Dutch cows were divided in 2 groups: one group received $100 \mathrm{~g} / \mathrm{day}$ of mineral salt supplement impregnated with tick biotherapic $12 \mathrm{cH}$ for 6 months, and then in alternate days with tick biotherapic $30 \mathrm{cH}$ to complete 28 months of treatment; the other group (control) received only the mineral salt supplement. After 28 months of treatment, engorged Rhipicephalus (boophilus) microplus females were collected in both groups, counted and weighed; in vitro tests were carried out to assess mass of ticks; egg mass; egg-hatching rate; and reproductive efficiency. Results: There was significant difference between both groups for all parameters evaluated; tick-mass $(p=0.0008)$; egg mass $(p=0.0044)$; egg-hatching rate $(p=0.0017)$; and reproductive efficiency $(p=0.0044)$. Conclusion: treatment with tick biotherapic significantly decreased the mass of engorged females, deposition and hatching rate of eggs, resulting consequently in the decrease of the reproductive efficiency of ticks.
\end{abstract}

Keywords: Homeopathy; Rhipicephalus microplus; Tick biotherapic; Controlled trial; Cows

\section{Introduction}

Tick Rhipicephalus (Boophilus) is extremely specific to cattle however it can also sporadically parasitize other species of animals [1]. As a mostly tropical country, the climate of Brazil favors the growth and survival of $R$. microplus [2].

This ectoparasite carries protozoa (Babesia bovis e Babesia bigemina) and prokaryotes (Anaplasma marginale), which cause babesiosis and anaplasmosis respectively, affecting severely the production of meat and milk in farms, as well as restricts the transit of animals [3]. Damage can be direct and indirect: the most significant causes of direct damage are the annoyance of animals by stings; the depletion of bodily nutrients due to the tick's sucking of blood and lymph; and the toxic effect of stings. Indirect damage includes tick-borne diseases and the expenses related to tick and disease control [4]. 
In the life cycle of $R$. microplus, only one host is needed. Mating of ticks usually occurs while they are on the host animal; afterwards, the female drops to the ground and after 2-6 days it begins to deposit eggs (about $3,000)$ that remain agglutinated. Oviposition lasts 15-20 days to finish when the females dies. The period of incubation lasts 6-7 days and depends on the environmental temperature and the relative humidity of the air. Freshly hatched larvae do not have infesting ability, but after 4-6 days they climb the stems of grass and wait for hosts to pass by [5].

As a rule, control of $R$. microplus in Brazil is grounded on bathing animals with pesticides once ticks are identified. The number of such baths can be very high varying with the method of application, time of the year, race of animals and cost of treatment [2]. However, the ability of this parasite to develop resistance to pesticides restricts their use and farmers tend to increase both the dose and the frequency of application [1]. Resistance of $R$. microplus to pesticides increases anywhere it finds favorable conditions to development; in Brazil, it was identified several populations resistant to different pesticides [6].

The main phenomena associated with resistance to pesticides are: alteration of the external tegument, decreasing the rate of penetration of drugs; metabolic changes leading to the storage and excretion of drugs; and dislocation of the target-action of drugs. Most pesticides are not sufficiently effective so that resistant ticks survive and activate their enzymatic defense system, transmitting to the offspring the resistance thus acquired [7].

Misuse of conventional pesticide agents together with the resistance against them developed by ticks, human and environmental contamination and the presence of residues in the marketed products add further problems related to these ectoparasites [8]. The indiscriminate use of chemicals affects the environment, animals and people, on the other hand, the use of natural products can minimize the ecological imbalance and the pollution of the environment [1]. Furthermore, since resistance to anti-parasite drugs develops so easily, the pharmaceutical industry hesitates to invest in developing new drugs. Although the time required to market a new drug is hard to estimate, it is certainly limited due to the fast development of resistance [9].

Control of endo- and ectoparasites through homeopathy and/or isopathy has been attempted several times in Brazil with good results [7]. The reasons adduced by producers to seek alternative approaches include: high cost of conventional treatment; emergence of drug resistance; human and environmental contamination; elimination of natural enemies; interest in entering the organic products market [10]. Veterinarians highlight 4 features to explain the growing use of homeopathy by farmers: effective results; lack of potential drug resistance; lack of sediment in food; and lower cost. A further advantage is that there is no need to observe a time-gap between the use of medicines and the trade of food-producing animals, decreasing dramatically financial losses [11].

For these reasons, the aim of the present study was to test a biotherapic preparation of $R$. microplus on dairy cattle to verify its potential efficacy in the control of this ectoparasite.

\section{Materials and Methods}

Biotherapic was prepared at the Pharmacotechnics and Homeopathy Laboratory of Universidade Paranaense (Unipar), Brazil, from engorged $R$. microplus females according to the procedures described by Brazilian Homeopathic Pharmacopeia (FHB) [12]. Live ticks were placed in contact with a liquid extractor containing water, ethanol and glycerin in proportion 1:1:1 for 20 days under agitation. The resulting solution was filtered, diluted and agitated until reaching dilution $12 \mathrm{cH}$. This dilution was used to impregnate mineral salt in proportion $10 \%$ according to the prescription for impregnation of powders in FHB; the compound was then dried in heaters at less than $50^{\circ} \mathrm{C}$. Mineral salt was chosen since it is a daily supplement for cattle. 
The study was carried out at farm São Tomé, Umuaruma, Paraná, Brazil. Thirty-four dairy Dutch cows were divided in 2 groups: Group I ( $\mathrm{n}=17)$ received plain mineral salt (negative control) and Group II ( $\mathrm{n}=17)$ received mineral salt impregnated with tick biotherapic $12 \mathrm{cH}$ (treated group). The batch of mineral salt was the same for both groups and the dose was $100 \mathrm{mg} /$ day. Both groups were kept in the same area but in different pastures to facilitate handling.

The study began in 27 January 2007. After 6 months, the dilution of tick biotherapic was changed to $30 \mathrm{cH}$ and the dose was administered on alternative days instead of daily.

After 28 months of treatment, on 29 March 2009 the engorged females of tick $R$. (B.) microplus were collected in both groups; selection criterion was maximal engorgement. Females were cleansed and evaluated regarding their integrity at maximum engorgement; 46 females were selected among the ones collected from the animals treated with biotherapic and 30 from the control group. They were transported to the Parasitology Laboratory of Unipar where it was carried out the in vitro tests described by Drumond [13].

The selected engorged females were individually weighed and identified before being distributed in 9-cm Petri dishes containing 10 ticks each. The experiment was repeated 3 times, totaling 30 females per group. The Petri dishes were incubated at $28^{\circ} \mathrm{C}$ for 14 days until oviposition; it was measured the egg-mass of each individual female. Then the eggs were placed in test-tubes kept at $27-28^{\circ} \mathrm{C}$ and $70-80 \%$ relative humidity for 21 days until eggs hatched.

\section{Results}

The parameters evaluated in this study through in vitro tests included: mass of ticks; egg mass; egg-hatching rate; and reproductive efficiency in both groups. It was observed homogeneity among the females chosen regarding their weight between both groups according to variance analysis. This parameter is crucial to establish the egg-hatching rate, since a poor distribution of weight can mask its results.

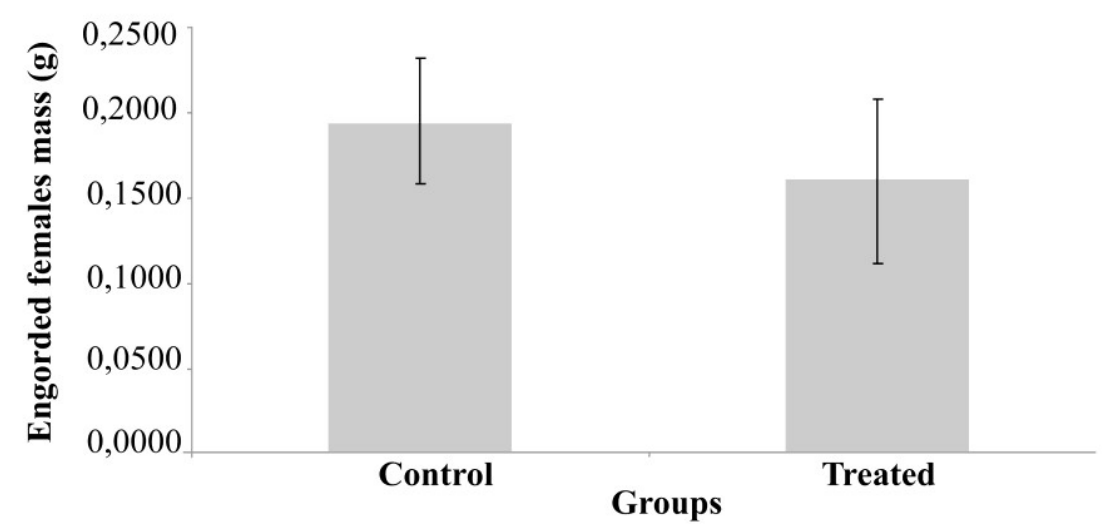

Figure 1: Mass of engorded females in the group treated with $R$. microplus biotherapic $12 \mathrm{cH}$ and $30 \mathrm{cH}$ and in the control group (t-test $\mathrm{p}=0.0008$ ).

Figure 1 depicts the results of tick mass in both groups. There was significant difference in the ticks mass between the treated and control groups $(p=0.0008)$, which means that the females that parasitized the treated group of cows had a lower mass gain than the ones that parasitized the control group.

Fourteen days after the ticks were placed in plates, the egg mass was measured; results are shown in Figure 2 ; there was significant difference between the treated and control groups. 


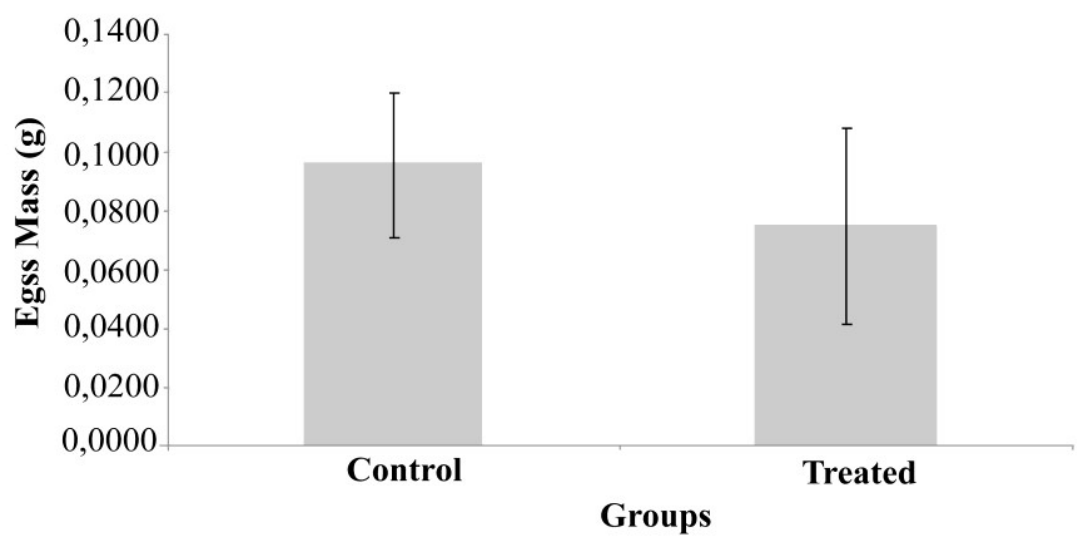

Figure 2: Egg mass of the group treated with R. microplus biotherapic $12 \mathrm{cH}$ and $30 \mathrm{cH}$ and of the control group (t-test $\mathrm{p}=0.0044)$.

Figure 3 represents the percentage of egg-hatching in the treated and control groups; there is significant difference between both groups, showing a lower egg-hatching rate in the treated group.

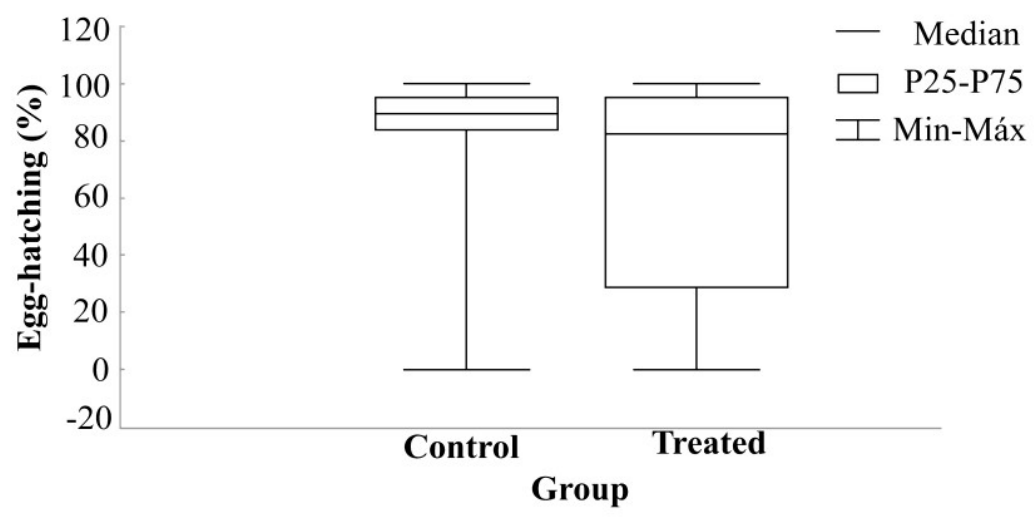

Figure 3: Percentage of egg-hatching in the group treated with $R$.(B.) microplus biotherapic $12 \mathrm{cH}$ and $30 \mathrm{cH}$ and in the control group (t-test $\mathrm{p}=0.0017$ ).

The results of reproductive efficiency are represented in Figure 4. 


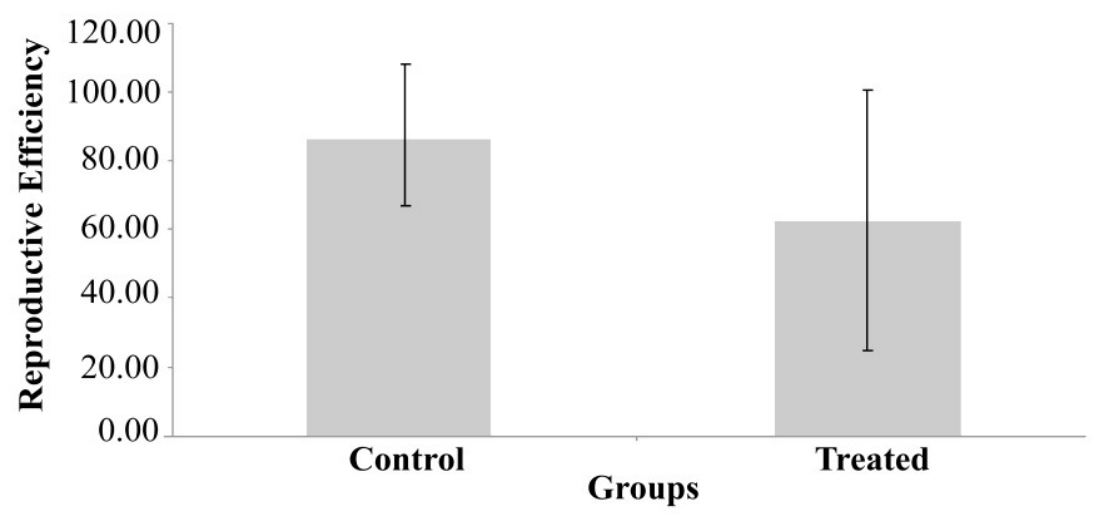

Figure 4: Reproductive efficiency of the group treated with $R .(B$.$) microplus biotherapic 12 \mathrm{cH}$ and $30 \mathrm{cH}$ and the control group. (t-test $\mathrm{p}=0.0044$ ).

$\mathrm{RE}$ was estimated according to equation 1, taking into account the weight of engorged females and eggs, the egg-hatching percentage and the approximate number of larvae per gram of eggs $(\simeq 20,000)$. Results show significantly lower $R E$ in the tick treated than in the control group $(p=0.0044)$.

$$
E R=\frac{\text { eggs weight }}{\text { engorged females weight }} x(\% \text { egg hatching }) x(20,000)
$$

\section{Discussion}

After 3 months of treatment, it was observed a decrease in the number and size of tick females in the cows treated with biotherapic. This allowed the farmer to decrease the frequency of pesticide baths, which was every 15 days before the study began, to every 2 months and then at gradually longer intervals, until at the end of the study no baths whatsoever were further needed.

Regarding the decrease in tick infestation, our results can be compared with the ones obtained by Neto [15], who also used homeopathic preparations mixed to a mineral supplement and observed a lowering of the infestation by ticks in the treated animals.

This decrease in tick infestation was also shown in the studies by Real [16], evaluating the control of ticks through population-homeopathy. This effect allowed widening the intervals between the administration of pesticides and insecticides resulting in a overall reduction in their use as long as homeopathic treatment was continued.

The significant difference of the egg mass between the treated and control groups can be explained as a consequence of the weight of females being significantly lower in the treated group than in the control group.

The in vitro tests still demonstrated the efficacy of the tick biotherapic on the egg-hatching rate, which was $50 \%(30-95 \%)$ in the treated group and $85-95 \%$ in the control group. This effect can also be explained as an 
effect of the reduction in the weight of females, with the corresponding decrease in egg mass and consequently, in the rate of egg hatching.

The experiment still included the estimation of the Reproductive Efficiency, which was about 22\% lower in the treated group compared to the control.

These results agree with the ones obtained by Verissimo [17], who used tick biotherapic in dilution 6cH and observed decrease in tick infestation in the animals included in the study. This decrease of the tick population was also observed by Arenalis [18], in whose study, after 7-10 days of ingested the blood of animals treated with homeopathic preparations, the ticks exhibited difficulty to feed and began to wither until acquiring the aspect of mummification. In Almeida's revision [19], some studies showed that the administrations of ultra diluted antigens is able to influence the immune modulating response; this may help to explain the effect of tick biotherapic on the life cycle of the parasite. Silva [20] used a biotherapic mixture on 27 Purunã heifers and showed significant effect on the control of infestation by $R$. microplus, with $50 \%$ reduction in the number of engorged females.

The use of dilutions $12 \mathrm{cH}$ and $30 \mathrm{cH}$ dilution is justified by Neto [15], who explains that concentrations $10^{9}-10^{-}$ ${ }^{23}$ correspond to the concentrations of hormones and neurotransmitters in the body.

Alternatives to tick control by using phytotherapy are shown by Farias [21], who evaluated the in vitro action of Carapa guianensis Aubl (andiroba) seed oil and obtained 100\% efficacy in the mortality and egg production of engorged B. microplus females. Borges [22] used hexane extracts of ripen fruits of Melia azedarach L. and observed an interference on the development of ticks on animals but not on their reproduction. On the other hand, Silva [23] observed a reduction in the reproductive parameters of ticks using Azadirachta indica and Cymbopogon citratus, probably due to interference on oviposition.

Further relevant data were supplied by Chagas [1], who tested diverse solvents on engorged females and measured egg deposition and hatching rate. The results allowed concluding that the liposoluble and vehicles solvents (alcohol, acetone) have the highest toxic effect on engorged females. These data ought to be taken into account when attempting to develop new pesticide drugs.

\section{Conclusion}

There was significant interference in the life cycle of ticks recovered from cows treated with tick biotherapic $12 \mathrm{cH}$ and $30 \mathrm{cH}$. In vitro tests showed mass reduction of engorged females, oviposition reduction, egg-hatching rate and reproductive efficiency.

\section{References}

[1] Chagas ACS, Leite RC, Furlong J, Prates HT, Passos WM. Sensibilidade do carrapato Boophilus microplus a solventes. Ciência Rural. 2003; 33(1): 109-114. [portuguese].

[2] Júnior JCBS, Furlong J, Daemon E. Controle do carrapato Boophilus microplus (Acari: Ixodidae) em sistemas de produção de leite da microrregião fisiográfica fluminense do Grande Rio- Rio de Janeiro. Ciência Rural. 2000; 30(2): 305-311. [portuguese]. 
[3] Minghua W, Guerrero FD, Pertes G, Vishvanath MN. Global comparative analysis of ESTs from the southern cattle tick, Rhipicephalus (Boophilus) microplus. BioMed Central [BMC Genomics]. 2007 [cited 2009 Oct 14]; 368(8). Available from: http://www.biomedcentral.com/1471-2164/8/368

[4] Heimerdinger A. Extrato alcoólico de capim-cidreira (Cymbompogon cittratus) no controle do carrapato (Boophilus microplus) de bovinos leiteiros [dissertation]. Santa Maria, RS (Brasil): Universidade Federal de Santa Maria; 2005. 78p. [portuguese].

[5] Fortes E. Parasitologia Veterinária. Ribeiro Martins. São Paulo: Ícone Editora; 1997. [portuguese].

[6] Farias NA, Ruas JL, Santos TRB. Análise da eficácia de acaricidas sobre o carrapato Boophilus microplus, durante a última década, na região sul do Rio Grande do Sul. Ciência Rural. 2008; 38(6): 1700-1704. [portuguese].

[7] Vivian MP. Uso do cinamomo (Melia azedarach) como alternativa aos agroquímicos no controle do carrapato bovino (Boophilus microplus) [dissertation]. Florianópolis, SC (Brasil): Universidade Federal de Santa Catarina; 2005.72p. [portuguese].

[8] Barci LAG, Nogueira AHC. Método para avaliação de mortalidade de larvas de Boophilus microplus (Canestrini,1887) submetidas a tratamentos com produtos carrapaticidas. Arq. Inst. Biol., São Paulo. 2006; 73(1): 105-109. [portuguese].

[9] Clemente MA, Gomes FT, Scotton ACS, Goldner MS, Reis ES, Almeida N. Avaliação do potencial de plantas medicinais no controle de Boophilus microplus (Acari: Ixodidae). Revista Brasileira de Biociências. 2007; 5(2): 516-518. [portuguese].

[10] Pitombo LH. Homeopatia avança no corte. Revista DBO Rural. 2002; 264(1): 178-181. [portuguese].

[11] Rudinger B. Pesquisa clinica em homeopatia veterinária. Homint R\&D Newsletter. 1998; 2(1): 19-22. [portuguese].

[12] Farmacopéia Homeopática Brasileira. 2nd ed. São Paulo: Atheneu; 1987. [portuguese].

[13] Drummond, RO., Ernst, ST., Trevino, JL. Boophilus annulatus and Boophilus microplus: laboratory tests for insecticides. Journal of Economic Entomology 1973, 66: 130-133.

[14] Souza AP, Bellato V, Sartor AA, Kolling A. Comparação da eficácia de carrapaticidas em testes a campo com de imersão "in vitro". Revista de Ciências Agroveterinárias. 2004; 3(2): 131-134. [portuguese].

[15] Neto MAM, Benedetti E, Cabral DD. Homeopatia no controle de carrapato em bovinos leiteiros [dissertation]. Uberlândia (Brasil): Universidade Federal de Uberlândia; 2004. 20p. [portuguese].

[16] Real CM. Homeopatia populacional. Agroecologia Hoje. 2003; 19(1): 12. [portuguese].

[17] Veríssimo CJ. Utilização do nosódio carrapatinum em bovinos sensíveis ao carrapato Boophilus microplus (Canestrini). Pesquisa Homeopática. 1988; 5(1): 21-25. [portuguese].

[18] Arenales MC. Homeopatia em gado de corte [online]. I conferencia virtual global sobre produção orgânica de bovinos de corte; 2002 September 02 - October 15; Corumbá (Brasil): Embrapa; 2002 [cited 2009 Oct 20]. Available from: http://www.cpap.embrapa.br/agencia/congressovirtual/pdf/portugues/02pt05.pdf. [portuguese]. 
[19] Almeida LR. Pesquisa em bioterápicos. Cultura Homeopática. 2006; 5(1): 6-17. [portuguese].

[20] Silva NL, Moletta JL, Minho AP, Filippsen LF. Use of biotherapic in the control of natural infestation by Boophilus microplus: pilot study. Int J High Dilution Res. 2008; 7(22): 36-38.

[21] Farias MPO, Sousa DP, Arruda AC, Arruda MSP, Wanderley AG, Alves LC, Faustino MAG. Eficácia in vitro do óleo da Carapa guianensis Aubl. (andiroba) no controle de Boophilus microplus (Acari: Ixodidae). Ver. Brás. PI. Med., Botucatu. 2007; 9(4): 68-71. [portuguese].

[22] Borges LMF, Ferri PH, Silva WC, Silva WJ, Melo LS, Souza LAD, Soares SF, Faria KA, Gomes NA, Mori A, Silva NF. Ação do extrato de frutos maduros de Melia azedarach (Meliaceae) sobre Boophilus microplus ( Acari: Ixodidae) em bezerros infestados artificialmente. Revista de Patologia Tropical. 2005; 34(1) 53-59. [portuguese].

[23] Silva WW, Athayde ACR, Rodrigues OG, Araujo GMB, Santos VD, Neto ABS, Coelho MCOC, Marinho ML. Efeitos do neem (Azadirachta indica A. Juss) e do capim santo [Cymbopogon citratus (DC) Stapf] sobre os parâmetros reprodutivos de fêmeas ingurgitadas de Boophilus microplus e Rhipicephalus sanguineus (Acari: Ixodidae) no semiárido paraibano. Rev. Brás. PI. Med.. 2007; 9(3):1-5. [portuguese].

\section{Eficiência de bioterápico de carrapato no controle da infestação por rhipicephalus (boophilus) microplus em vacas leiteiras de raça holandesa}

\section{RESUMO}

Introdução: os carrapatos do gado Rhipicephalus (Boophilus) microplus representam um sério problema para os criadores brasileiros, especialmente porque desenvolvem rapidamente resistência aos pesticidas. Por isso, junto a outros fatores incluindo contaminação ambiental, humana e animal, assim como os custos, têm sido procuradas abordagens alternativas. Objetivos: avaliar a eficiência de um bioterápico desenvolvido a partir de carrapatos em vacas infestadas. Métodos: 34 vacas leiteiras de raça holandesa foram divididas em 2 grupos; um recebeu $100 \mathrm{mg} /$ dia de suplemento salino mineral impregnado com o bioterápico 12cH durante 6 meses e após $30 \mathrm{cH}$ em dias alternos até completar 28 meses de tratamento; o outro grupo (controle) recebeu só o suplemento mineral. Após 28 meses de tratamento foram coletadas fêmeas ingurgitadas do carrapato em ambos os grupos, contadas e pesadas, e foram realizados testes in vitro para determinar a massa de parasitas; massa de ovos; taxa de eclosão dos ovos; e eficiência reprodutiva. Resultados: houve diferença significativa entre ambos os grupos em todos os parâmetros avaliados - massa de parasitas ( $p=0,0008)$; massa de ovos $(\mathrm{p}=0,0044)$; taxa de eclosão de ovos $(\mathrm{p}=0,0017)$ e eficácia reprodutiva $(0,0044)$. Conclusão: o tratamento com bioterápico de carrapato diminuiu significativamente a massa de fêmeas ingurgitadas e a deposição e taxa de eclosão, resultando, consequentemente, na diminuição da eficiência reprodutiva dos carrapatos.

Palavras-Chave: Homeopatia; Rhipicephalus microplus; Bioterápico de carrapato; Estudo controleado; Vacas Eficiencia de bioterápico de garrapata para control de la infestación por Rhipicephalus (Boophilus) microplus en vacas lecheras de raza holandesa

\section{RESUMEN}

Introducción: la garrapata del ganado Rhipicephalus (Boophilus) microplus produce serios problemas a los hacenderos brasileños especialmente porque desarrolla rápidamente resistencia a los agentes pesticidas. Por este motivo, asociado a otros factores como contaminación ambiental, humana y animal y los costos, se buscan abordajes alternativos. Objetivos: este estudio buscó evaluar la eficiencia de un bioterápico preparado de garrapatas en vacas infestadas. Métodos: 34 vacas lecheras de raza holandesa fueron divididas en 2 grupos; 
uno recibió 100 mg/día de suplemento mineral impregnado con bioterápico 12cH durante 6 meses y después, en días alternados hasta completar 28 meses de tratamiento; el otro recibió apenas el suplemento mineral (control). Después de 28 meses de tratamiento, garrapatas hembra ingurgitadas fueron recogidas en ambos grupos, contadas y pesadas; fueron realizados pruebas in vitro para medir la masa de garrapatas; la masa de huevos, la tasa de eclosión de huevos y la eficiencia reproductiva. Resultados: hubo diferencias significativas entre los 2 grupos en todos los parámetros evaluados - masa de garrapatas ( $p=0,0008)$, masa de huevos $(p=0,0044)$, tasa de eclosión de huevos $(p=0,0017)$ y eficiencia reproductiva $(p=0,0044)$. Conclusión: el tratamiento con bioterápico de garrapata redujo significativamente la masa de hembras ingurgitadas y la deposición y eclosión de huevos, resultando en disminución de la eficacia reproductiva de las garrapatas.

Palabras-Llave: Homeopatía; Rhipicephalus microplus; Bioterápico de garrapata; Ensayo controlado; Vacas

\section{(cc) EY-NC-ND Licensed to GIRI}

Support: authors declare that this study received no funding Conflict of interest: authors declare there is no conflict of interest

Received: 09 September 2010; Revised: 29 November 2010; Published: 20 December 2010.

Correspondence author: Zilda Cristiani Gazin, Umuarama - PR - Brazil. zcgazin@uol.com.br.

How to cite this article: Gazim ZC, Ferreira FBP, da Silva AV, Bolognese KC, Merlin E, Messa V, de Jesus RA, Coutinho CA, da Silva LCM. Efficiency study of the tick biotherapic in the infestation control of Rhipicephalus (boophilus) microplus on dairy cows of the dutch race. Int J High Dilution Res [online]. 2010 [cited YYYY Month dd]; 9(33): 156-164. Available from: http://www.feg.unesp.br/ ojs/index.php/ijhdr/article/view/407/447 . 